\title{
Edukacja akademicka osób niepełnosprawnych a ich aktywność na rynku pracy
}

\section{Wstęp: rola pracy i wykształcenia w życiu człowieka}

Niepełnosprawność dotyka w Polsce prawie 4,5 miliona osób, czyli około 12 proc. całej społeczności ${ }^{1}$. Oznacza to, że co ósmy Polak ma ograniczoną sprawność, która utrudnia pełne funkcjonowanie w życiu społecznym $\mathrm{w}$ tym mieszczą się także ograniczenia związane $\mathrm{z}$ edukacją prowadzące często do bierność zawodowej.

Edukacja i praca to dwie ważne sfery w życiu każdego człowieka, które decydują o rozwoju jednostki, a tym samym wpływają na poziom rozwoju całego społeczeństwa. Pierwsza kształtuje osobowość, samoocenę, światopogląd człowieka, z kolei druga tworzy nowe wartości, przyczynia się do wzrostu dobrobytu jednostki i całego społeczeństwa. W pewnym stopniu

1 GUS, Narodowy Spis Powszechny Ludności i Mieszkań 2011, Ludność i gospodarstwa domowe. Stan i struktura ekonomiczno-społeczna. Część I. Ludność, stat.gov.pl/spisypowszechne/nsp-2011/nso-2011-wyniki/ludnosc-i-gospodarwstwa-domowe-stani-struktura-spoleczno-ekonomiczna-czesc-i-ludnosc-nsp-2011,11,1.html (dostęp: 2.05.2015). 
114 obie wartości prowadzą do uzyskania autonomii od kogoś lub czegoś, dając tym samym poczucie szczęścia.

Z komunikatu CBOS wynika, że blisko dwie piąte Polaków zalicza siebie do ludzi, którym sprzyja szczęście. Trzykrotnie mniej jest takich, którzy czują, że na ogół mają w życiu pecha, a co drugi respondent stwierdza, że bywa z tym różnie. Zadowolenie z życia częściej deklarują najmłodsi respondenci, w tym uczniowie i studenci, oraz ludzie mający wyższe wykształcenie i dobrze sytuowani. Relatywnie najwięcej niezadowolonych osób jest wśród najstarszych Polaków, będących w złej sytuacji materialnej oraz w grupie rencistów ${ }^{2}$.

Uzależnienie poczucia satysfakcji z życia od wykonywania pracy jest szczególnie nasilone wśród osób niepełnosprawnych. Jak wskazuje literatura, długotrwały brak pracy prowadzi do głębokich zmian w psychospołecznym funkcjonowaniu człowieka niepełnosprawnego. Brak zatrudnienia wśród osób niepełnosprawnych wywołuje poczucie wzmożonej frustracji zmierzającej do zaburzenia poziomu własnej samooceny ${ }^{3}$. Niepracujące osoby niepełnosprawne istotnie rzadziej myślą o sobie jako o osobach wartościowych, częściej zaś czują się bezużyteczne i uważają, iż są do niczego (tabela 1). Z kolei takie spostrzeganie własnej osoby znacząco obniża motywacje osoby z niepełnosprawnością do ciągłej walki, często syzyfowej, o lepszą jakość zdrowia i większy komfort życia.

Tabela 1. Praca zarobkowa a poczucie własnej wartości [w \%].

\begin{tabular}{|l|c|c|}
\hline \multicolumn{1}{|c|}{ Odpowiedzi wskazane przez respondentów } & Pracujący & Niepracujący \\
\hline Myślę, że jestem wartościową jednostką, nie gorszą od innych. & $95,8 \%$ & $82,4 \%$ \\
\hline $\begin{array}{l}\text { Większość rzeczy jestem w stanie robić równie dobrze jak inni } \\
\text { ludzie. }\end{array}$ & $95,1 \%$ & $72,3 \%$ \\
\hline $\begin{array}{l}\text { Robiąc plany, mam na ogół pewność, że będę w stanie je } \\
\text { zrealizować. }\end{array}$ & $80,1 \%$ & $55,1 \%$ \\
\hline $\begin{array}{l}\text { Czasem czuję, że mało jest takich rzeczy, z których } \\
\text { mogę być dumny. }\end{array}$ & $26,2 \%$ & $37,8 \%$ \\
\hline
\end{tabular}

2 CBOS, Zadowolenie z życia - komunikat z badań 2015, nr 3 (2015), http://www.cbos.pl/ SPISKOM.POL/ 2015/K_003_15.PDF (dostęp: 5.05.2015).

3 Pentor Research International, Badania wpływu kierunku i poziomu wykształcenia na aktywność zawodową osób niepełnosprawnych. Raport końcowy, cz. 1, http://www.pfron.org.pl/ ftp/dokumenty/Badania_i_an alizy/Raport_CZESC_1z6_final.pdf (dostęp: 23.05.2015). 


\begin{tabular}{|l|c|c|}
\hline \multicolumn{1}{|c|}{ Odpowiedzi wskazane przez respondentów } & Pracujący & Niepracujący \\
\hline Czasem myślę, że w ogóle nie daję się do niczego. & $17,7 \%$ & $30,3 \%$ \\
\hline Czasem czuję się bezużyteczny. & $15,5 \%$ & $29,9 \%$ \\
\hline
\end{tabular}

Źródło: E. Giermanowska, Znaczenie pracy w życiu młodzieży niepełnosprawnej, [w:] Młodzi niepełnosprawni o sobie - rodzina, edukacja, praca, pod red. E. Giermanowskiej, Warszawa 2007, s. 103.

Nie inaczej jest w kwestii wykształcenia, które istotnie wpływa na poziom samooceny oraz poziom satysfakcji z życia wśród osób niepełnosprawnych ${ }^{4}$. Waga wykształcenia jest o tyle istotna, iż w obecnych czasach jest ona silnie związana z aktywnością zawodową wśród wszystkich ludzi. Tymczasem aktywność zawodowa ma na celu poprawienie sytuacji materialnej jednostki. Funkcja dochodowa pracy jest szczególnie istotna dla osób niepełnosprawnych, gdyż bezpośrednio łączy się z większymi możliwościami lepszego leczenia i rehabilitacji.

Rolą edukacji jest wspieranie integracji społecznej oraz rehabilitacji zawodowej, która wpływa na bierność lub aktywność badanej populacji. Z corocznych badań aktywności ekonomicznej Polaków BAEL wynika, że im lepsze wykształcenie, tym większa szansa na zatrudnienie. Dane z ubiegłych lat jednoznacznie wskazują, że niepełnosprawni z wyższym wykształceniem pracują najczęściej (33 proc.) spośród wszystkich niepełnosprawnych. W charakterystyce tej najniżej plasują się osoby z wykształceniem gimnazjalnym i niższym (7 proc.), w której to grupie szczególnie uwydatniają się wysokie bezrobocie i bierność zawodowa ${ }^{5}$.

Omawiając rolę wykształcenia na rzecz aktywizacji zawodowej, nie sposób pominąć funkcji samej aktywności i bierności zawodowej w pryzmacie budżetu państwa. W Polsce niepełnosprawni obok emerytów stanowią najliczniejszą grupą świadczeniobiorców pobierających rentę. Wedle danych ZUS w 2013 roku wydatki na świadczenia związane z niezdolnością do pracy wyniosły ogółem 32 276,1 mln zł. Z kolei dane KRUS na temat liczby rent

4 R. Śleboda, Kierunek i poziom wykształcenia oraz aktywność zawodowa osób niepełnosprawnych, http://www.pfron.org.pl/kn/poprzednie-numery/118, Kierunek-i-poziomwyksztalcenia-oraz-aktywnosc-zawodowa-osob-z-niepelnosprawnosc.html (dostęp: 17.05.2015).

5 Źródło: GUS BAEL z lat 2009-2013, dotyczy osób niepełnosprawnych w wieku 15 i więcej, http://stat.gov.pl/ rocznik i_PLK_HTML.htm (dostęp: 1.05.10.2015). 
116 z tytułu niezdolności do pracy wykazały ponad $533 \mathrm{mln}$ zł wydatków. Ostanie lata dowodzą, że najwyższy odsetek w wydatkach na świadczenia związane $\mathrm{z}$ niezdolnością do pracy stanowiły wydatki na renty z tytułu niezdolności do pracy (około 50 proc. ogółu świadczeń) ${ }^{6}$. Tak ogromne koszty plasują Polskę w światowej czołówce państw pod względem wielkości udziału wydatków na świadczenia rentowe w PKB.

Co ważne i godne podkreślenia, dla osób niepełnosprawnych praca i edukacja to dodatkowo pewnego rodzaju osobiste potwierdzenie umiejętności radzenia sobie z ograniczeniami własnego ciała i umysłu. To sposób na życie.

\section{Wielowymiarowa niepełnosprawność rynku pracy}

Rynek pracy, w dużym uproszeniu, obejmuje podaż pracy oraz popyt na pracę. W stosunku do osób niepełnosprawnych charakteryzuje się pewnego rodzaju dualnością, polegającą na funkcjonowaniu dwóch obszarów: otwartego rynku pracy oraz rynku pracy chronionej.

Polski rynek pracy nie jest rynkiem łatwym - zarówno dla osób pracujących, jak i poszukujących pracy, ani dla sprawnych, ani niepełnosprawnych. Charakteryzuje się wysokim i często długotrwałym bezrobociem ludzi młodych i niepełnosprawnych; niedopasowaniem poziomu kwalifikacji do potrzeb rynku pracy oraz zróżnicowaniem przestrzennym lokalnych rynków pracy ze względu na nierównomierny rozwój gospodarczy poszczególnych regionów. Wszystkie zjawiska przenikają się i łączą, powodując 11-12 proc. bezrobocia osób w wieku produkcyjnym i ponad 16 proc. wśród samych niepełnosprawnych ${ }^{7}$.

Analiza bezrobocia i bierności zawodowej wśród osób niepełnosprawnych wymaga generalnie podejścia wielowymiarowego, ale w tym wypadku selektywnego. Biorąc pod uwagę napotykaną terminologię, kluczowe jest rozróżnienie pojęć określających badaną populację. Jest to o tyle ważne, iż według polskiego prawa posiadanie statusu osoby niepełnosprawnej istotnie wpływa na możliwości niepełnosprawnego poszukującego pracy, w tym

6 ZUS, Wydatki na świadczenia z ubezpieczeń społecznych zwiąane z niezdolnością do pracy w 2013 r., Departament Statystyki i prognoz aktualnych, Warszawa 2015, s. 9, 11, 37.

7 GUS BAEL z lat 2009-2013, http://stat.gov.pl/ rocznik i_PLK_HTML.htm (dostęp: 5.10.2015). 
bezrobotnego, oraz możliwość podejmowania przez niego pracy i jej wykonywania. Z kolei pracodawców obliguje do prawidłowych postaw i działań na rzecz pracownika ze stwierdzoną niepełnosprawnością ${ }^{8}$.

Zgodnie z Ustawą o rehabilitacji zawodowej i społecznej oraz zatrudnieniu osób niepełnosprawnych za osobę niepełnosprawną uważa się osobę, której stan fizyczny lub psychiczny czy umysłowy trwale bądź okresowo utrudnia, ogranicza albo uniemożliwia wypełnianie ról społecznych, a w szczególności zdolności do wykonywania pracy zawodowej. Uzyskanie statusu osoby niepełnosprawnej wymaga posiadania orzeczenia wydanego przez odpowiedni organ ${ }^{10}$ : o zakwalifikowaniu do jednego z trzech stopni niepełnosprawności; o całkowitej lub częściowej niezdolności do pracy; o rodzaju i stopniu niepełnosprawności osoby, która nie ukończyła 16 roku życia ${ }^{11}$.

Powszechnie uznaje się, że orzeczenia wystawione przez upoważnione do tego organy są równoważne, ale nie stanowi to reguły, ponieważ jedne służą do celów rentownych, z kolei drugie do celów pozarentownych. Dualność źródeł orzekania jest częstą przyczyną nieporozumień z prawem do świadczenia i szczególnych uprawnień osób niepełnosprawnych. Ponadto nieporozumienia pogłębia nieprecyzyjnie i niepoprawnie interpretowana nomenklatura stopni niepełnosprawności.

Aktywność zawodową niepełnosprawnych warunkuje w głównej mierze orzeczenie o niezdolności do wykonywania jakiejkolwiek pracy, które uniemożliwia zatrudnienie oraz orzeczenie o pracy tylko w warunkach specjalnych, co paraliżuje podjęcie pracy w sytuacji, gdy w pobliżu miejsca zamieszkania nie ma zakładu pracy chronionej ${ }^{12}$.

W literaturze oraz statystykach pracy i ubezpieczeń społecznych obok prawnego rozróżnienia funkcjonuje również pojęcie osoby niepełnospraw-

8 B. Kołeczek, Rynek pracy osób niepełnosprawnych - podstawowe pojęcia i ogólna charakterystyka, [w:] Rynek pracy osób niepełnosprawnych. Sytuacje klęsk żywiołowych, pod red. B. Olszewskiej, Warszawa 1999, s. 11-12.

9 Art. 1 Ustawy o rehabilitacji zawodowej i społecznej oraz zatrudnianiu osób niepełnosprawnych z dnia 27.08.1997r. (Dz.U. 1997 Nr 123 poz. 776, ze późn. zm.).

10 Osoby niepełnosprawne mogą uzyskać oficjalne, administracyjne uznanie ich niepełnosprawności, występując o wydanie orzeczenia o stopniu niepełnosprawności. Dokument taki wydają Powiatowe Zespoły ds. Orzekania o Niepełnosprawności oraz lekarze orzecznicy ZUS lub KRUS.

11 A. Kogut, I. Sierpowska, Status osoby niepełnosprawnej w polskim systemie prawa, Wrocław 2010, s. 35-38.

12 A. Kogut, I. Sierpowska, Status osoby niepełnosprawnej.., dz. cyt., s. 35-43. 
118 nej biologicznie, czyli osoby niemającej prawnego orzeczenia o stanie niepełnosprawności, ale odczuwającej ograniczoną zdolność do wykonywania czynności podstawowych ${ }^{13}$.

Istotnymi czynnikami aktywności zawodowej osób niepełnosprawnych są rodzaj i stopień schorzenia jednostki oraz sytuacja na rynku pracy, a przede wszystkim liczba i rodzaj ofert kierowanych bezpośrednio (rynek pracy chronionej) i pośrednio (otwarty rynek pracy) do niepełnosprawnych $\mathrm{z}$ danymi schorzeniami.

Posiadanie statusu osoby niepełnosprawnej wywołuje szereg pozytywnych, ale też negatywnych konsekwencji zarówno dla samego niepełnosprawnego, jak i jego (potencjalnego) pracodawcy.

Do pozytywnych regulacji względem niepełnosprawnych należą ochrona przed nadmiernym czasem pracy, prawo do dodatkowych dni wolnych i przerwy w pracy. Ponad to pracownik niepełnosprawny ma pewnego rodzaju prawną gwarancję dostosowania miejsca i stanowiska pracy do potrzeb wynikających $\mathrm{z}$ jego stanu zdrowia ${ }^{14}$. Tymczasem pracodawcy mogą skorzystać m.in. ze zwolnienia z wpłat do PFRON, zwrotu kosztów przystosowania i wyposażenia stanowiska pracy, zwrotu kosztów szkolenia pracownika niepełnosprawnego oraz dofinansowania do wynagrodzeń pracownika niepełnosprawnego ${ }^{15}$. Z drugiej strony pracodawcy, którzy chcą wykorzystać tego typu możliwości, muszą liczyć się z ogromnymi obwarowaniami prawno-administracyjnymi, które mogą zniechęcać do zatrudnienia niepełnosprawnego. Prawo obliguje pracodawcę do stworzenia takich warunków pracy dla niepełnosprawnego pracownika, które odpowiadają wymogom określonym w przepisach. Z kolei to, co określają przepisy dla stwierdzonego stopnia niepełnosprawności, nie zawsze jest adekwatne wobec faktycznego stanu zdrowia pracownika ze statusem osoby niepełnosprawnej. W konsekwencji posiadanie statusu utrudnia podjęcie pracy tejże osobie, która chce i byłaby w stanie ją wykonywać. Owe przepisy prawa są często rażąco niepraktyczne i niepokojące, a nawet rodzą wobec osób niepełnosprawnych pewnego rodzaju przemoc instytucjonalną, prowadzącą do porażki

13 B. Kołeczek, Rynek pracy osób niepełnosprawnych..., dz. cyt., s. 12.

14 Biuro Pełnomocnika Rządu ds. Osób Niepełnosprawnych, Niepełnosprawny pracownik, http://www.niepelnosprawni.gov.pl/p,62, niepelnosprawny-pracownik (dostęp: 10.06.2015).

15 Biuro Pełnomocnika Rządu ds. Osób Niepełnosprawnych, Uprawnienia pracodawcy zatrudniającego osobę niepełnosprawna, http://www.niepelnosprawni.gov.pl/p,67,uprawnieniapracodawcy-zatrudniajacego-osobe-niepelnosprawna (dostęp: 10.06.2015). 
na płaszczyźnie pracownik-pracodawca. Należy pamiętać, że orzeczenie o niepełnosprawności jest dokumentem usankcjonowanym prawnie, ale jest też jedynie ogólną przesłanką medycznie zaobserwowanych dysfunkcji organizmu. Sama symbolika przyczyny niepełnosprawności zawarta w ww. orzeczeniach tylko teoretycznie odzwierciedla rozpoznanie uszkodzenia lub choroby, która niezależnie od przyczyny jej powstania powoduje zaburzenia funkcji organizmu oraz ograniczenia w wykonywaniu czynności życiowych i aktywności społecznej osoby zainteresowanej. Co oznacza, że posiadanie statusu osoby niepełnosprawnej wyłącznie uogólnia cechy stanu zdrowia organizmu człowieka według dysfunkcji, które ta osoba ma, ale nie określa jej w kategorii jednostki. Z kolei wychodząc od faktu, że każdy człowiek jest inny, należy stwierdzić: każda niepełnosprawność jest inna. Dlatego osoba $z$ dysfunkcją organizmu powinna mieć możliwość zdecydowania, czy potrzebuje warunków specjalnych do pracy, a jeśli tak, to jakich, gdyż tylko ona wie, czy jest zdatna do pracy oraz czy zastane stanowisko pracy wystarcza jej w wypełnieniu obowiązków wynikających ze stosunku pracy.

$\mathrm{Z}$ danych bezrobocia wynika, że udział osób niepełnosprawnych wśród ogółu osób zarejestrowanych w urzędach pracy pod koniec 2014 roku wynosił 6,5 proc., podczas gdy wśród zarejestrowanych jako bezrobotni wyniósł 5,6 proc., a wśród zarejestrowanych jako poszukujący pracy 47,7 proc. Tymczasem według SODiR w ubiegłym roku zarejestrowało się 243 tys. osób niepełnosprawnych, z czego 103,6 tys. osób było zatrudnionych na otwartym rynku pracy, a 139,3 tys. osób pracowało w zakładach pracy chronionej ${ }^{16}$.

Bardziej optymistycznie wygląda raport $\mathrm{z}$ danych analitycznych BAEL za 2014 rok, w którym zauważono minimalny spadek bezrobocia i lekki wzrost wskaźnika zatrudnienia osób niepełnosprawnych, który plasuje się na poziomie 22,8 proc. Obecny wynik nie jest zadawalający, ale świadczy o wzroście zatrudnienia osób niepełnosprawnych pomimo odczuwalnych nadal skutków kryzysu gospodarczego (rycina 1).

Od lat nie zmienia się charakterystyka grupy pracujących osób niepełnosprawnych. Najczęściej są to osoby z lekkim (43 proc.) i umiarkowanym stopniem niepełnosprawności (47 proc.). Najrzadziej pracują osoby o znacznym stopniu niepełnosprawności, co wynika z powagi ich stanu zdrowia i trudności pozyskania pracy ${ }^{17}$. W ubiegłym roku znaczną większość

16 Biuro pełnomocnika Rządu ds. Osób Niepełnosprawnych, Rynek pracy, http://www.nie pelnosprawni. gov.pl/p,80,rynek-pracy (dostęp: 02.06.2015).

17 GUS, NSP z 2011, Pracujące osoby niepełnosprawne w wieku 16. lat i więcej wg stopnia niepełnosprawności, http://stat.gov.pl/spisy-powszechne/nsp-2011/ (dostęp: 11.05.2015). 
Rycina 1. Wskaźnik zatrudnienia osób niepełnosprawnych w wieku produkcyjnym w latach 2004-2014 [w \%].

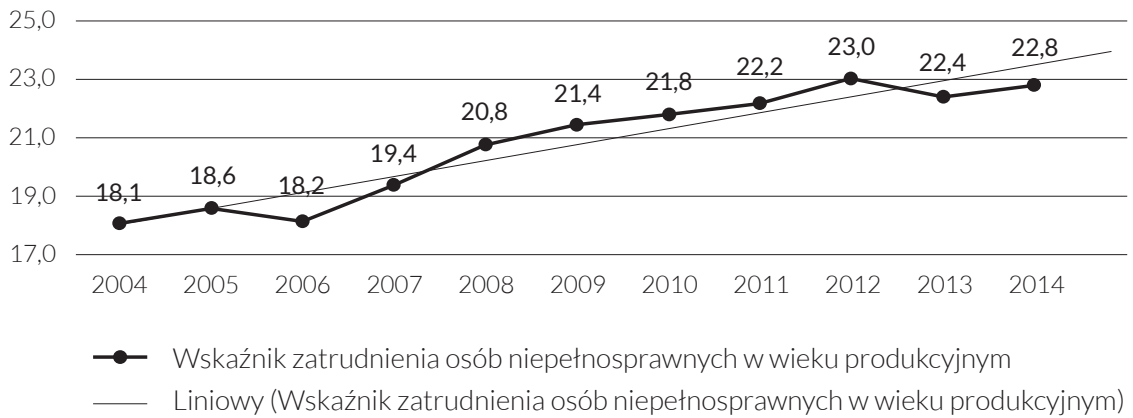

Źródło: GUS BAEL, Osoby niepetnosprawne na rynku pracy w IV kwartale 2014 r. Podsumowanie roku 2014, http://niepelnosprawni.gov.pl/container/niepelnosprawnosc-w-liczbach/rynek-pracy/Dane\%20 analityczne \%20 podsumowanie\%20za\%20IV\%20kwartal\%202014\%20r.\%202015.04.24.pdf (dostęp: 17.05.2015).

pracowników niepełnosprawnych stanowili pracownicy najemni. Udział tej grupy wśród pracujących niepełnosprawnych w wieku 16 lat i więcej wynosił 79 proc., a wśród osób w pracujących w wieku produkcyjnym 81 proc. ${ }^{18}$. Nie należy zapominać, że powyżej przedstawione dane prezentują jedynie 20 proc. społeczności niepełnosprawnych aktywnych zawodowo wśród wszystkich niepełnosprawnych, gdyż resztę stanowią osoby bierne zawodowo $(80 \text { proc. })^{19}$.

Ogrom zjawiska bierności zawodowej osób niepełnosprawnych staje się szczególnie widoczny w kontekście danych dotyczących aktywności zawodowej osób sprawnych. W ostatnich latach liczba niepełnosprawnych biernych zawodowo jest niemal dwukrotnie wyższą niż w całej populacji osób w wieku produkcyjnym; w przypadku 85 proc. badanych bierność ma charakter trwały. Niepełnosprawni dużo częściej niż osoby sprawne doświadczają problemów na rynku pracy, będących eskalacją ich stanu zdrowia oraz wielu innych czynników wewnętrznych (np. kompetencje, motywa-

18 GUS, BAEL, Osoby niepełnosprawne na rynku pracy w IV kwartale 2014 r. Podsumowanie roku 2014, http://niepelnosprawni.gov.pl/container/niepelnospr awnosc-w-liczbach/rynekpracy/Dane\%20analityczne \%20 podsumowanie\%20za\%20IV\%20kwartal\%2020 14\% 20r.\%202015.04.24.pdf (dostęp: 17.05.2015).

19 GUS, NSP z 2002r. oraz NSP z 2011 r., analiza porównawcza pokazuje, iż udział procentowy aktywności i bierności zawodowej osób niepełnosprawnych jest w obu spisach taki sam. 
cja) i zewnętrznych (np. brak ofert pracy, stereotypy o niepełnosprawnych, chaos prawny itp. $)^{20}$.

W raporcie końcowym dla PFRON stwierdzono, że ponad połowa niepełnosprawnych biernych zawodowo zwyczajnie nie chce pracować, a zdecydowaną chęć wyraża niespełna co dziesiąty bierny zawodowo. Większą motywację do podjęcia pracy wykazują ludzie młodzi, choć i w tym przypadku liczba gotowych podjąć pracę od zaraz tylko lekko przekracza jedną trzecią, a wśród osób $\mathrm{z}$ wykształceniem podstawowym jest nawet niższa ${ }^{21}$. Tymczasem badania aktywności ekonomicznej BAEL pod koniec 2014 roku pokazują, że wśród osób niepełnosprawnych największą grupą biernych zawodowo były osoby, które ukończyły co najwyżej szkoły gimnazjalne (49 proc.), oraz osoby $z$ wykształceniem zasadniczym zawodowym (31 proc.). Z kolei dużo mniejszą bierność zawodową wykazywali niepełnosprawni Z wykształceniem średnim ogólnokształcącym (11 proc.) oraz policealnym i średnim zawodowym (7 proc.). Najwyższą aktywność wykazywały osoby z dyplomem ukończenia studiów, których bierność zawodowa wynosiła jedynie 2 proc. - najmniej w całej badanej populacji ${ }^{22}$.

Z literatury przedmiotu wynika, że wśród osób niepełnosprawnych występują obok siebie zarówno braki w zakresie kształcenia fachowego, jak i braki w zakresie umiejętności społecznych potrzebnych do aktywnego poszukiwania pracy $^{23}$.

\section{Studia w liczbach}

Dane GUS pokazują, że od lat 90. w polskim społeczeństwie rośnie współczynnik scholaryzacji brutto na poziomie wyższym (z 12,9 proc. w roku

20 R. Śleboda, Kierunek i poziom wykształcenia oraz aktywność zawodowa osób z niepełnosprawnościq, http://www.pfron.org.pl/kn/poprzednie-numery/118,Kierunek-i-poziomwyksztalcenia-oraz-aktywnosc-zawodo wa-osob-z-niepelnosprawnosc.html (dostęp: 17.04.2015).

21 R. Śleboda, Kierunek i poziom wykształcenia..., dz. cyt.

22 GUS, BAEL, Badanie aktywności ekonomicznej ludności, http://stat.gov.pl/download/gfx/ portalinfor macyjny/pl/defaultaktualnosci/5475/2/19/1/kwartalna_informacja_o_aktyw nosci_ekonomicznej_ludnosci_4kw2014.pdf (dostęp: 16.04.2015).

23 J. Bartkowski, E. Giermanowska, Nietypowe formy zatrudnienia osób niepetnosprawnych - analiza rynku ofert pracy i roli Powiatowych Urzędów Pracy - Wnioski i rekomendacje, [w:] Młodzi niepetnosprawni - aktywizacja zawodowa i nietypowe formy zatrudnienia, pod red. E. Giermanowskiej, Warszawa 2007, s. 160. 
122 akademickim 1990/1991 do 49,2 proc. w roku 2013/2014)24. Oznacza to, że zwiększa się rola edukacji akademickiej w życiu społecznym, tym również w życiu osób niepełnosprawnych. Niestety rzeczywistość wskazuje, że niepełnosprawni są gorzej wykształceni niż osoby sprawne ${ }^{25}$ oraz częściej niż inni ludzie narażeni na izolację społeczną. Brak wykształcenia jest problemem dotykającym przede wszystkim osoby ze znacznym stopniem niepelnosprawności, które często wymagają kształcenia przez odpowiednie organizowanie nauki do potrzeb osoby niepełnosprawnej oraz edukacji publicznej.

Pozytywnym zjawiskiem ostatnich lat jest stopniowy wzrost udziału osób niepełnosprawnych mających wyższe wykształcenie, który jest efektem złożonego procesu poprawy komfortu życia osób z niepełnosprawnością, w tym dostosowania uczelni do potrzeb osób z niepełnosprawnością, aprobaty społecznej i budowania świadomości praw wśród samych niepełnosprawnych ${ }^{26}$. W 2011 roku nastały także zmiany w przepisach ustawy Prawo o szkolnictwie wyższym, które nałożyły na uczelnie wyższe dodatkowy podstawowy obowiązek „stworzenia osobom niepełnosprawnym warunków do pełnego udziału w badaniach naukowych"27. Na mocy tejże ustawy uczelnie otrzymują środki celowe, przeznaczone na dofinansowanie lub finansowanie kosztów realizacji inwestycji, w tym służących kształceniu studentów i doktorantów niepełnosprawnych. Jest to ważna nowelizacja, zważywszy na fakt, iż dotychczasowy dostęp do instytucji akademickich uzależniony był jedynie od otwartości oraz dobrej woli władz danej uczelni ${ }^{28}$.

Z publikacji GUS Szkoly wyższe i ich finanse wynika, że w pierwszych 15 latach po transformacji liczba studentów niepełnosprawnych wzrosła aż pięciokrotnie. Intensywny wzrost zanotowano między rokiem akademickim 2004/2005 a 2005/2006, w którym to czasie liczba studentów niepelnosprawnych wzrosła z 9247 do 19923. Kolejne lata ukazywały wzmożoną

24 GUS, Szkoły Wyższe i ich finanse, 2013 r., Warszawa 2014, s. 30.

25 Poziom wykształcenia ludności wśród sprawnych i niepełnosprawnych osób w 2013 roku: gimnazjalne, podstawowe lub brak wykształcenia: 19,8 proc. - sprawni, 32,8 proc. niepełnosprawni; policealne i średnie zawodowe: 23 proc. - sprawni, 23 proc. - niepełnosprawni; średnie ogólnokształcące: 10 proc. - sprawni, 7,5 proc. - niepełnosprawni; wyższe: 22,2 proc. - sprawni, 7,7 proc. - niepełnosprawni. GUS, Szkoły wyższe i ich finanse, 2013 r., Warszawa 2014, s. 30.

26 Pentor Research International, Badania wpływu kierunku..., dz. cyt.

27 Art. 13 ust. 1 pkt 9, art. 94 ust. 1 pkt 11 oraz 4 Ustawy Prawo o szkolnictwie wyższym z dnia 27.07.2005 r., (Dz.U. Nr 164, poz. 1365, ze zm.).

28 A. Żebrak, Edukacja osób z niepełnosprawnością na poziomie szkolnictwa wyższego, http:// ngoteka.pl/bitstr eam/handle/item/32/edukacja_osob_z_niepelnosprawnoscia_na_pozio mie_szkolnictwa_wyzszego.pdf?sequence=1 (dostęp: 13.04.2015). 
aktywność studentów z dysfunkcjami, choć w nieco mniejszym nasileniu.

Eskalacja zjawiska nastąpiła w roku 2012/2013: liczba studentów niepełnosprawnych wyniosła 31613, stanowiąc największy jak do tej pory udział niepełnosprawnych wśród ogółu studentów ( 1,89 proc.). W następnym roku liczba ta spadła do 28940 osób ${ }^{29}$.

Obecna liczba osób niepełnosprawnych na studiach jest nadal imponująca, biorąc pod uwagę początek lat 90., kiedy liczba niepełnosprawnych studentów była znikoma, a jeszcze wcześniej wręcz niezauważalna. Nie należy jednak sądzić, że na polskich uczelniach wyższych takich osób nie było. Były, ale albo na tyle nieliczne, albo ich niepełnosprawność była na tyle niewidoczna, że praktycznie nie odnotowywano ich w statystykach. Ustalenie rzeczywistej liczby studentów niepełnosprawnych do dziś stanowi pewien kłopot. Niektóre osoby (studenci) pomimo odczuwania niepełnosprawności biologicznej nie mają statusu osoby niepełnosprawnej lub nie chcą się do tego przyznaćso.

Zauważalny ostatnio spadek liczby osób niepełnosprawnych nie jest zaskoczeniem wśród analityków, zważywszy na zachodzące w populacji Polaków zmiany demograficzne, które wykazują cechy społeczeństwa starzejącego się. Badania nad stanem zdrowia ludności wskazują jednoznacznie na ścisły związek między wiekiem a niepełnosprawnością ${ }^{31}$. Z tego powodu obniżoną liczbę studentów niepełnosprawnych tłumaczy się jako wynik podwyższenia struktury średniego wieku Polaków, co daje ogólny spadek wszystkich osób studiujących.

Powyższe dane pokazują, że coraz więcej niepełnosprawnych podejmuje się zdobywania wyższego wykształcenia pomimo wielu trudności. Obok problemów zdrowotnych wynikających z niepełnosprawności, które same w sobie są niebagatelną przeszkodą, niepełnosprawni mierzą się z barierami w zastanej rzeczywistości (architektonicznymi i komunikacyjnymi, społecznymi i prawnymi).

Istniejące bariery bezpośrednio wpływają na fakt, iż niepełnosprawne osoby dużo rzadziej niż ich rówieśnicy decydują się na studia. W konse-

29 GUS, Szkoły wyższe i ich finanse, lata 1998-2014.

30 Brak informacji o niepełnosprawności studenta uniemożliwia korzystania z praw wynikających z posiadania statusu osoby niepełnosprawnej, np. stypendiów dla osób niepełnosprawnych, dofinansowań kształcenia (czesne, podręczniki, dojazdy do i z uczelni, uczelnie, zakwaterowanie) w ramach programu Aktywny samorząd realizowany przez PCPR ze środków PFRON.

31 Narodowy Instytut Zdrowia Publicznego - Państwowy Zakład Higieny, Sytuacja zdrowotna ludności polski 2012, http://www.pzh.gov.pl/stan-zdrowia-ludnosci/ (dostęp: 17.05.2015). 
124 kwencji dystans dzielący pod tym względem niepełnosprawnych od reszty społeczeństwa zamiast się zmniejszać, raczej rośnie (tabela 2).

Tabela 2. Ogólna liczba osób studiująca z wyszczególnieniem liczby studentów niepełnosprawnych oraz ich udziałem z pośród wszystkich studentów w latach akademickich 1997/1998-2013/2014.

\begin{tabular}{|c|c|c|c|}
\hline Rok akademicki & $\begin{array}{c}\text { Liczbawszystkich } \\
\text { studentów }\end{array}$ & $\begin{array}{c}\text { Liczba studentów } \\
\text { niepełnosprawnych }\end{array}$ & $\begin{array}{c}\text { Studenci } \\
\text { niepełnosprawni } \\
\text { spośród wszystkich } \\
\text { studentów }\end{array}$ \\
\hline $1997 / 98$ & 1082657 & 826 & $0,08 \%$ \\
\hline $2010 / 11$ & 1841251 & 30096 & $1,63 \%$ \\
\hline $2012 / 13$ & 1676927 & 31613 & $1,89 \%$ \\
\hline $2013 / 14$ & 1549877 & 28940 & $1,87 \%$ \\
\hline
\end{tabular}

Źródło: opracowanie własne za: GUS, Szkoły wyższe i ich finanse, lata 1998-2014.

Chcąc wykazać, w jakim stopniu edukacja akademicka wpływa na aktywność zawodową osób niepełnosprawnych, nie sposób pominąć liczby absolwentów niepełnosprawnych, czyli osób, które ukończyły na jakimś etapie studia i są gotowe - bardziej merytorycznie niż praktycznie - wejść na rynek pracy. Należy to zauważyć, pamiętając, iż samo być studentem nie oznacza mieć wyższe wykształcenie. Owa zasada dotyczy wszystkich studentów. Wyższe wykształcenie to nie coś przyznanego z automatu, ale wartość zdobywana wysiłkiem intelektualnym, któremu nie wszyscy mogą sprostać. Wielu studentów przerywa edukację akademicką z różnych względów, mniej lub bardziej zależnych od nich samych. Dodatkowo „być studentem z niepełnosprawnością” oznacza „radzić sobie z własną niepełnosprawnością i uzależnieniem od kogoś lub czegoś”.

Od 2006 do 2013 roku polskie uczelnie opuściło 45689 niepełnosprawnych absolwentów szkół wyższych, z czego w samym roku akademickim 2012/2013 aż 8199. Prawie co trzeci absolwent miał dysfunkcję ruchu, ale był osobą chodzącą (27-30 proc.). Prawie co dziesiąty absolwent był niewidomy lub słabowidzący (8-9 proc.), a co czternasty miał problemy ze słuchem lub był niesłyszący (6-7 proc.) ${ }^{32}$. Z powodu licznych barier architektonicznych, w tym barier występujących na uczelniach i w najbliższym otoczeniu osób 
niepełnosprawnych, najrzadziej kończyły studia osoby poruszające się na wózkach inwalidzkich (niechodzące), stanowiąc jedynie 1-2 proc. wśród ogółu absolwentów niepełnosprawnych. U większości niepełnosprawnych absolwentów występowały inne niż wskazane rodzaje niepełnosprawności, które szacunkowo wahały się między 53 a 59 proc. $^{33}$ (rycina 2).

Rycina 2. Ogólna liczba absolwentów niepełnosprawnych z uwzględnieniem udziału procentowego według rodzaju niepełnosprawności za okres lat akademickich: 2006/2007-2012/2013.

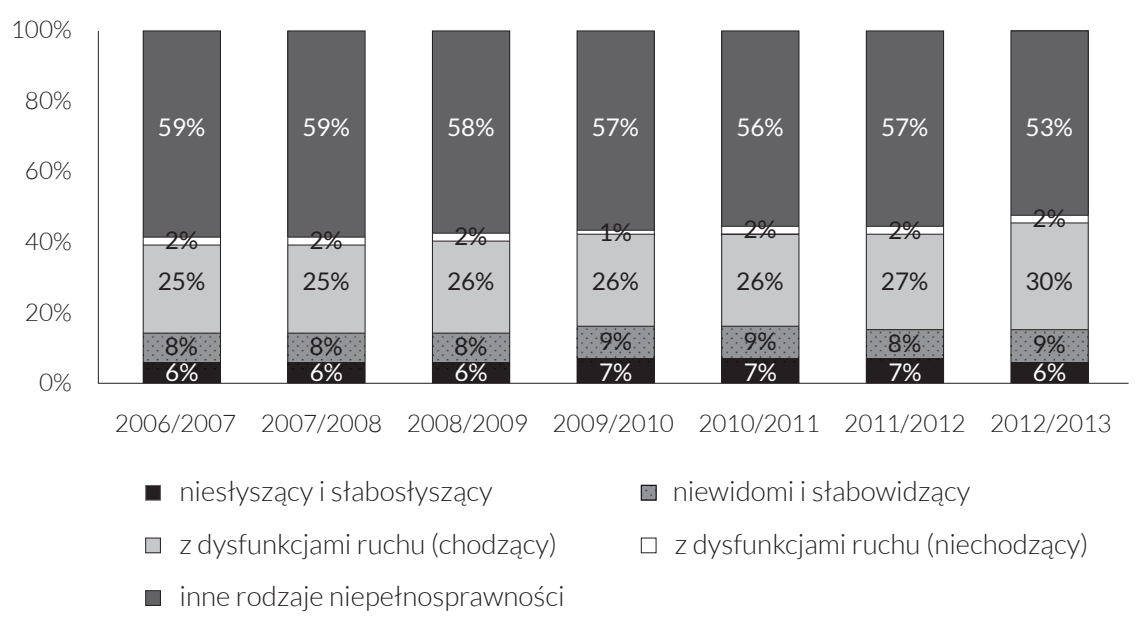

Źródło: opracowanie własne, za: GUS, Szkoły wyższe i ich finanse, za lata akademickie 2006/20072012/2013

\section{Zawiedzione aspiracje}

Raport Edukacja w zarysie, będący kompendium informacji o systemach edukacyjnych w krajach OECD i partnerskich, pokazał, że „im więcej lat spędzonych na edukacji, tym większa szansa na zatrudnienie i lepsze zarobki”34. Z drugiej strony, jak dowodzi cytowana przez Danutę Gorajewską Hanna Żuraw, studia wyższe zwiększają szansę zatrudnienia, ale go nie gwarantują ${ }^{35}$. Niestety większość z osób niepełnosprawnych z wyższym wykształceniem dużo częściej

33 GUS, Szkoły wyższe i ich finanse, lata akademickie 2006/2007-2012/2013.

34 R. Śleboda, Kierunek i poziom wykształcenia..., dz. cyt.

35 D. Gorajewska, Wartość człowieka, [w:] Społeczeństwo równych szans - tendencje i kierunki zmian, pod red. D. Gorajewskiej, Warszawa 2005, s. 23. 
126 niż ich zdrowi rówieśnicy z tym samym wykształceniem pozostaje poza rynkiem pracy. Sytuacja nie jest obiecująca, tym bardziej że niepełnosprawni pytani o motywacje, jakie kierowały nimi przy podejmowaniu decyzji o rozpoczęciu studiów, najczęściej odpowiadali, że chcieli podnieść swoje kwalifikacje (65 proc.) oraz zwiększyć własne szanse na rynku pracy (65 proc.) ${ }^{36}$.

Bierność zawodowa absolwentów niepełnosprawnych szkół wyższych to najczęściej nie wynik lenistwa, które zaraz po braku wykształcenia i kompetencji według pracodawców jest największą barierą aktywizacji zawodowej niepełnosprawnych, lecz kumulacja barier zewnętrznych i wewnętrznych (stanu zdrowia, wieku, wsparcia emocjonalnego, statusu społecznego, opinii na temat pracy, strachu przed ośmieszeniem).

Do barier zewnętrznych przed podejmowaniem pracy należą szczególnie:

1. zmienne przepisy i nadmierna biurokracja przy zatrudnianiu niepełnosprawnych,

2. system orzecznictwa i system ubezpieczeń społecznych, które wzmacniają wśród niepełnosprawnego strach przed utratą świadczenia społecznego - często jedynego źródła dochodów,

3. słabość wsparcia instytucjonalnego, a dokładnie brak odpowiedniego do potrzeb rynku pracy systemu kształcenia,

4. izolacja wynikająca ze stereotypów na temat osób niepełnosprawnych (słaby, chorowity, niewydajny), która uniemożliwia niepełnosprawnym partycypację w różnych obszarach życia na tych samych warunkach co osobom sprawnym,

5. nieodpowiedni stan przystosowania stanowiska pracy oraz warunków koniecznych do dojazdu do miejsca pracy ${ }^{37}$.

Wszystkie bariery znacząco wpływają na motywacje i możliwości zatrudnienia wśród niepełnosprawnych. Zdecydowana większość absolwentów niepełnosprawnych jest jednak gotowa podjąć pracę od zaraz (63,3 proc.). Tylko co dziesiąty nie ma takiego zamiaru (10,5 proc.), a reszta chcę pracować, ale nie od zaraz $\left(29,35\right.$ proc.) ${ }^{38}$. Stąd wniosek, iż niepełnosprawni z wyższym wykształceniem do pracy podchodzą w sposób nie tylko punitywny, ale głównie autoteliczny, a nie instrumentalny ${ }^{39}$.

\footnotetext{
36 R. Śleboda, Kierunek i poziom wykształcenia..., dz. cyt.

37 R. Śleboda, Kierunek i poziom wykształcenia..., dz. cyt.

38 R. Śleboda, Kierunek i poziom wykształcenia..., dz. cyt.

39 Trzy modele podejścia jednostki do wykonywanej pracy: autoteliczny - wartość sama w sobie, instrumentalny - środek do uzyskania korzyści materialnych, punitywny - zło konieczne. B. Szczupał, Sytuacja zawodowa osób niepełnosprawnych..., dz. cyt., s. 76-81.
} 
Skutki istniejących barier odczuwają również sami (potencjalni) pracodawcy otwartego rynku pracy, wśród których rejestruje się rozbieżność pomiędzy werbalnymi deklaracjami a postawami rzeczywistymi wobec niepełnosprawnych. Werbalne deklaracje są najczęściej determinowane konsekwencjami i normami społecznymi oraz obawą przed negatywną oceną społeczną ${ }^{40}$. Tymczasem doświadczenia osób niepełnosprawnych poszukujących zatrudnienia potwierdzają, iż na obecnym otwartym rynku pracy realnie istnieje ukryta dyskryminacja osób z niepełnosprawnością, która chowana pod płaszczem przepisów ujawnia etykietowanie pracowników niepełnosprawnych jako osób chorowitych, niesamodzielnych, niewydajnych i generujących koszty przedsiębiorstwa oraz odpowiednich do pracy, ale tylko w ZPCH lub ZAZ.

Niechęć pracodawców ujawnia się w szczególności wobec osób niewidomych (90 proc.) i lekko niedowidzących (60 proc.), osób niesłyszących (77 proc.), chorych na schizofrenię (79 proc.) oraz epilepsję ( 65 proc.). Natomiast co drugi pracodawca nie ma nawet zamiaru zatrudnić osoby jeżdżącej na wózku inwalidzkim (59 proc.), a trzech na stu miałoby z tym problem. Najmniejsze uprzedzenia pracodawcy wykazują w stosunku do osób $\mathrm{z}$ trudnościami w chodzeniu (40 proc.) oraz w stosunku do osób niedosłyszących, z kolei co drugi chętnie zatrudniłby pracownika z niedowładem ręki (50 proc. $)^{41}$. Nie jest przekłamaniem, że w obawie przed wymienionymi komplikacjami systemowymi spora grupa pracodawców zatrudnia osoby sprawne, mimo że kandydat niepełnosprawny ma identyczne lub większe kompetencje potrzebne na danym stanowisku. Konkurencja zawodowa pomiędzy osobami sprawnymi i niepełnosprawnymi jest pożądanym i naturalnym procesem kapitalistycznego rynku pracy, ale do momentu gdy nie dyskryminuje żadnej grupy zawodowej. $\mathrm{Z}$ drugiej strony istnieją oferty pracy kierowane wyłącznie do osób niepełnosprawnych, ale oferowana w nich jakość pracy często jest poniżej umiejętności lub w innym zakresie kwalifikacji osób z wykształceniem wyższym oraz w oderwaniu od normalnego środowiska pracy ${ }^{42}$. Sama treść ogłoszeń pozostawia wiele do życzenia - nieraz wymagane są wyłącznie orzeczenie o stopniu niepełnosprawności i kompetencje miękkie. Pracodawcy bardzo rzadko wymagają

40 Z. Woźniak, Główne bariery aktywności zawodowej osób z ograniczona sprawnością, [w:] Osoby z ograniczoną sprawnością na rynku pracy, red. A. Brzezińska, Z. Woźniak, K. Maj, Warszawa 2007, s. 76.

41 ZUS, Pracodawcy o zatrudnieniu osób niepełnosprawnych, Warszawa 2009, s. 25.

42 E. Giermanowska i in., Niedokończona emancypacja..., dz. cyt., s. 203-207. 
128 od osób niepełnosprawnych wykształcenia wyższego, dobrej znajomości języka obcego czy programu komputerowego. Ponadto w badaniach wskazuje się na częsty problem pracodawców, którzy zatrudniają pracowników niepełnosprawnych głównie dla uzyskania zwolnień i korzyści od PFRON z tytułu zatrudniania osób niepełnosprawnych, a nie ze względu na kompetencje tych osób. Spora liczba zakładów pracy, chcąc utrzymać status przedsiębiorstwa zatrudniającego osoby niepełnosprawne, spełnia formalne przepisy zakładu zwolnionego $\mathrm{z}$ wpłat do PFRON, ale zatrudnione w nich osoby niepełnosprawne często są pracownikami widmo, czyli osobami widniejącymi w statystykach zakładu, lecz w rzeczywistości niepracującymi.

Powyższy obraz sytuacji słusznie może demotywować osoby niepełnosprawne do podnoszenia kwalifikacji poprzez zdobywanie wyższego wykształcenia. Do podjęcia studiów nie zachęcają wnioski z badań wpływu kierunku i poziomu wykształcenia na aktywność zawodową osób niepełnosprawnych sporządzonych dla PFRON. Stwierdza się w nich, że „sam poziom wykształcenia nie wspiera gotowości do podejmowania pracy. Z kolei [...] biorąc nawet pod uwagę pośrednie oddziaływanie poziomu wykształcenia, czynnik ten na tle innych, przede wszystkich zewnętrznych [...] w bardzo ograniczonym zakresie wpływa na sytuację osób niepełnosprawnych na rynku pracy"43.

Zła ocena zastanej rzeczywistości osób niepełnosprawnych na rynku pracy wyłania się również z opinii samych zainteresowanych. Najczęściej nie widzą oni większej szansy na pozytywne zakończenie poszukiwań pracy, a co gorsza często nawet nie podejmują próby jej znalezienia, tkwiąc w przekonaniu, że są bez szans. Nie oznacza to jednak, że brak perspektyw zatrudnienia dla osób niepełnosprawnych na rynku pracy wynika jedynie z lepiej czy gorzej prowadzonych działań polityki społecznej. Z kolei posądzanie każdego pracodawcy o chęć uzyskania jedynie korzyści finansowych z tytułu zatrudniania osoby niepełnosprawnej wydaje się niestosowne i wysoce niesprawiedliwe.

Osoby niepełnosprawne, poprzez z góry przybrane negatywne nastawienie do rynku pracy, często same stają się ofiarami. Pozytywne doświadczenia na rynku pracy, rzadko będące ich udziałem, automatycznie kreują ich negatywne nastawienie do otoczenia (np. „każdy będzie mnie obserwować”, „Z pewnością miejsce pracy będzie przeszkodą"), opinie demonizujące pracodawców (np. „przyjmie kogoś zdrowego”, „przyjął mnie dla własnych korzy- 
ści”) lub niską samoocenę (np. „będę tylko problemem”, „nie poradzę sobie”)

(rycina 3). W efekcie taka postawa osób z niepełnosprawnością przyczynia się do ich samoistnego wycofania się zarówno z życia zawodowego, jak i z życia społecznego. Utwierdza badaną populację w błędnym przekonaniu, że nie warto inwestować we własne kwalifikacje zawodowe (studiować), bo sam fakt bycia niepełnosprawnym minimalizuje szanse na wykonywanie ciekawej, satysfakcjonującej i dobrze płatnej pracy. Z kolei taka postawa umacnia społeczeństwo w zaściankowej opinii, że „osoby niepełnosprawne nie muszą pracować, bo mają rentę z tytułu niezdolności do pracy”, a poza tym „nie można normalnie funkcjonować i cieszyć się życiem, gdy jest się niepełnosprawnym”.

W związku z powyższym osoby z niepełnosprawnością muszą pamiętać, że ich brak wiary w swoje umiejętności nie prowadzi do zmiany stereotypu na temat niepełnosprawnego pracownika - czyli do zmian, o które walczą, lecz buduje kolejne bariery wewnętrzne. Co gorsze, negatywne podejście badanej populacji może demotywować całe społeczeństwo do skuteczniejszych działań aktywizacyjnych i integracyjnych na rzecz osób z niepełnosprawnością.

Rycina 3. Interaktywny model demotywacji w zdobywaniu wykształcenia wyższego wśród osób niepełnosprawnych wynikający z negatywnych doświadczeń na rynku pracy.
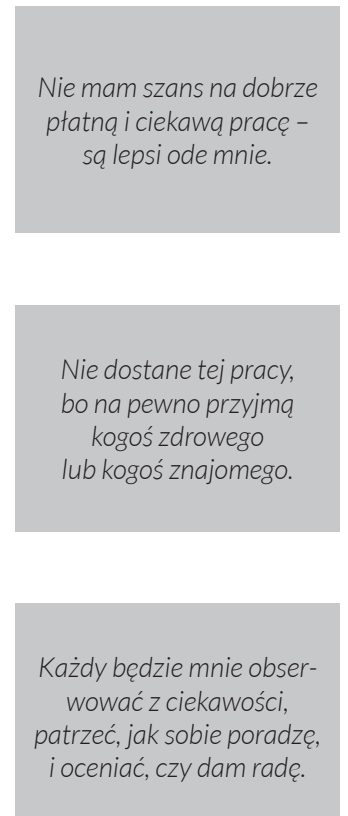

Źródło: opracowanie własne.
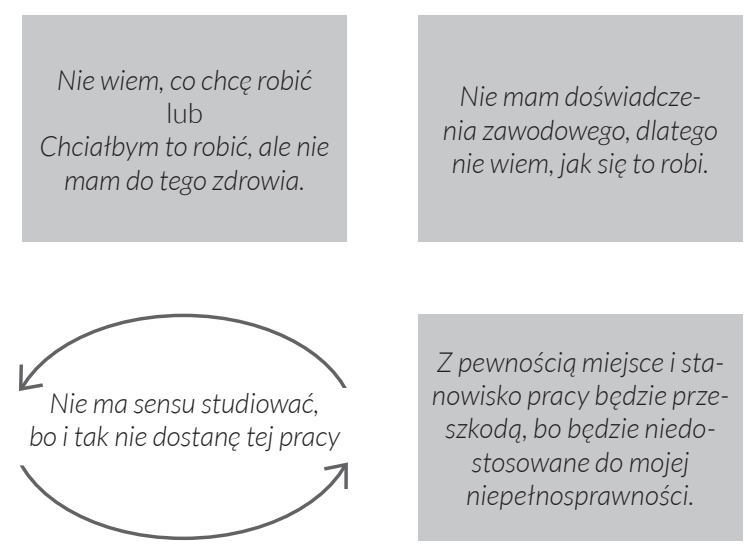

Dostatem prace, bo dużo umiem i jestem w tym dobry czy dlatego, że pracodawca chce skorzystać z dofinansowań i nie płacić kary do PFRON?
Nikt nie chce niepotrzebnych problemów pracodawca tym bardziej i dlatego mnie odrzuci. 
Wśród niepełnosprawnych Polaków wzrasta świadomość istoty wykształcenia, które w obecnych czasach jest silnie związane z aktywnością zawodową. O wadze tego spostrzeżenia świadczą nie tylko statystyki, ale osobiste doświadczenia osób poszukujących pracy. Mimo że obecny spadek liczby studentów niepełnosprawnych jest wytłumaczalny ze względów demograficznych, niepokoi wyhamowanie procentowego wzrostu udziału tej grupy osób wśród ogółu studentów. Od paru lat oscyluje on poniżej granicy 2 proc., której nie może przekroczyć, a nawet zaczyna się od niej oddalać. Najbliższe lata pokażą, czy obecnie występujący spadek procentowego udziału studentów niepełnosprawnych w stosunku do ogółu studentów jest przejawem chwilowego wahania ciągle rosnącej koniunktury, czy będzie trwałą zmianą tendencji. Potwierdzenie pierwszego przypuszczenia jest o tyle ważne, że pozwoli ustalić, a w przyszłości zniwelować kolejne bariery ograniczające osobom niepełnosprawnym uzyskiwanie wyższego wykształcenia. Z kolei drugie przypuszczenie, czyli utrzymanie się na tym samym poziomie udziału studentów niepełnosprawnych, pomimo wprowadzania różnorodnych udogodnień ze strony uczelni wyższych i państwa oraz postępu w medycynie i technologii mających na celu poprawę komfortu życia i studiowania może sugerować całkowite zaspokojenie potrzeby edukacji akademickiej wśród grupy niepełnosprawnych. Z innej strony może to być pewnego rodzaju odpowiedź osób niepełnosprawnych na tendencje polskiego rynku pracy, który nadal lekceważy potencjał, zaangażowanie oraz zdobyte kompetencje zawodowe tej grupy zawodowej.

Marginalizacja, a zarazem pewnego rodzaju deprecjacja osób niepełnosprawnych, w największym stopniu uwidaczniają niski współczynnik aktywności zawodowej oraz wykształcenia na poziomie wyższym. A przecież, jak słusznie zauważyła Danuta Gorajewska, pełnię człowieczeństwa osoby niepełnosprawne mogą osiągnąć dzięki rozwojowi, zmianie, pracy i nauce.

The schooling of disabled people and their active participation on the labor market

Every student seems to be aware of the fact that higher education makes it possible to obtain not only satisfying and rewarding but also well-paid job. This is certainly true in connection with the disabled people, who go to universities. In real life, higher 
education that they get, provides them with more opportunities on the labor market, but, in fact, it does not contribute to any form of competitiveness between them.

Employers, however, tend to discriminate the handicapped, because of the fact that such people appear to be considered either as non-efficient or non-effective. This common belief may lead to the high rate of unemployment among this group.

Being conscious of the obstacles that they may encounter on, more and more disabled people commence to go to universities to improve their professional skills and become more desirable on the marketplace.

The annual reports, based on The CSO data, have revealed that there rate of the handicapped who have finished their degrees, is gradually skyrocketing. Still, however, they number of highly qualified disabled people is lower than those healthy ones, which additionally exacerbate the professional inactivity of the former.

The majority of the disabled finish their education on the level of either vocational or comprehensive schools and very few of them, in comparison with their healthy peers, go to universities. The above described situation may have the plethora of economic and social reasons. The abundance of personal (low self-esteem), financial (lack of stable incomes) and physical (physical constraints) problems; and the external barriers, for instance, lack of suitable didactic equipment for the blind, lack of the interpreter of sign language for the deaf-and-dumb, or the limitations of buildings, may be one of the basic causes of discouraging the disabled to get further education. Only few of them, despite a growing number of governmental incentives, the improvement of didactic facilities and financial support of National Fund for the Rehabilitation of Disabled, are willing to fight for their better professional and personal future.

Keywords: disability, student, professional activity

\section{Edukacja akademicka osób niepełnosprawnych a ich aktywność na rynku pracy}

Każdy student wychodzi z założenia, że zdobycie wyższego wykształcenia daje gwarancje satysfakcjonującej i dobrze płatnej pracy. Z takiego założenia wychodzą również osoby niepełnosprawne podejmujące studia. W rzeczywistości bardzo często wyższe wykształcenie u osób niepełnosprawnych daje jedynie większą szansę wejścia na rynek pracy, a nie wpływa bezpośrednio na poziom ich konkurencyjności zawodowej.

Wysokie bezrobocie osób niepełnosprawnych ujawnia wśród pracodawców ukryte tendencje do dyskryminowania tych osób. Pracodawcy bardzo często nie zatrudniają osób niepełnosprawnych, kierując się stereotypem, iż jest to pracownik niewydajny i nisko konkurencyjny.

Osoby niepełnosprawne, świadome swojej trudnej sytuacji na rynku pracy, coraz odważniej podejmują edukację akademicką, która ma podnieść ich kompetencje i atrakcyjność zawodową. 
W corocznych sprawozdaniach Biura Pełnomocnika Rządu do spraw osób niepełnosprawnych na temat edukacji osób niepełnosprawnych, pisanych w oparciu o dane Głównego Urzędu Statystycznego, zauważa się rosnący udział osób niepełnosprawnych z wyższym wykształceniem. W tych samych publikacjach podkreśla się również, że osoby niepełnosprawne są wciąż znacznie gorzej wykształcone niż osoby sprawne, co dodatkowo potęguje ich bierność zawodową.

Wiele osób niepełnosprawnych kończy swoją edukację na poziomie szkoły średniej lub zawodowej i tylko nieliczni z nich, w stosunku do swoich pełnosprawnych rówieśników, podejmują studia. Niewielka liczba studentów niepełnosprawnych wynika z wielu przyczyn natury społecznej i ekonomicznej. Kumulacja problemów osobistych (niska samoocena), fizycznych (ograniczona zdolność poruszania się i komunikacji) i finansowych (brak lub ograniczona kwota dochodów pieniężnych) osób niepełnosprawnych oraz występowanie licznych barier zewnętrznych (np. ograniczona dostępność architektoniczna budynków edukacyjnych dla niepełnosprawnych ruchowo, brak odpowiedniego sprzętu dydaktycznego dla osób niewidomych i słabowidzących, brak tłumacza języka migowego dla osób głuchoniemych) często niwelują ambicje zdobywania wiedzy. Tylko nieliczne osoby niepełnosprawne, pomimo zachęty i udogodnień środowiska akademickiego oraz pomocy finansowej Państwowego Funduszu Rehabilitacyjnego Osób Niepełnosprawnych, podejmują walkę o swoją lepszą przyszłość osobistą i zawodową.

Słowa kluczowe: niepełnosprawność, student, aktywność zawodowa

\section{Bibliografia}

\section{Akty prawne}

Ustawa Prawo o szkolnictwie wyższym z dnia 27 lipca 2005 roku, Dz.U. Nr 164, poz. 1365, ze zm.

Ustawa o rehabilitacji zawodowej i społecznej oraz zatrudnianiu osób niepełnosprawnych z dnia 27 sierpnia 1997 roku, Dz.U. 1997 Nr 123 poz. 776, ze zm.

Bartkowski J., Giermanowska E., Nietypowe formy zatrudnienia osób niepełnosprawnych analiza rynku ofert pracy i roli Powiatowych Urzędów Pracy - Wnioski i rekomendacje, [w:] Młodzi niepełnosprawni - aktywizacja zawodowa i nietypowe formy zatrudnienia, pod red. E. Giermanowskiej, Warszawa 2007, s. 160.

Giermanowska E., Znaczenie pracy w życiu młodzieży niepełnosprawnej, [w:] Młodzi niepełnosprawni o sobie - rodzina, edukacja, praca, pod red. E. Giermanowskiej, Warszawa 2007, s. 103.

Giermanowska E. i in., Niedokończona emancypacja - niepełnosprawni absolwenci szkół wyższych na rynku pracy, [w:] Polacy niepełnosprawni - od kompleksowej diagnozy 
do nowej polityki społecznej, pod red. B. Gąciarz, S. Rudnickiego, Kraków 2014, s. 203-207.

Gorajewska D., Wartość człowieka, [w:] Społeczeństwo równych szans - tendencje i kierunki zmian, pod red. D. Gorajewskiej, Warszawa 2005, s. 23.

Kołeczek B., Rynek pracy osób niepełnosprawnych - podstawowe pojęcia i ogólna charakterystyka, [w:] Rynek pracy osób niepełnosprawnych. Sytuacje klęsk żywiołowych., pod red. B. Olszewskiej, Warszawa 1999, s. 11-12.

Kogut A., Sierbkowska I., Status osoby niepełnosprawnej w polskim systemie prawa, Wrocław 2010.

Woźniak Z., Główne bariery aktywności zawodowej osób z ograniczona sprawnościa, [w:] Osoby z ograniczona sprawnością na rynku pracy, pod red A. Brzezińskiej, Z. Woźniaka, K. Maja, Warszawa 2007, s. 76.

Zakład Ubezpieczeń Społecznych, Pracodawcy o zatrudnieniu osób niepełnosprawnych, Warszawa 2009.

Zakład Ubezpieczeń Społecznych, Wydatki na świadczenia z ubezpieczeń społecznych związane z niezdolnością do pracy w 2013 r., Warszawa 2015.

Biuro Pełnomocnika Rządu ds. Osób Niepełnosprawnych, Niepełnosprawny pracownik, http://www.niepelnos prawni.gov.pl/p,62,niepelnosprawny-pracownik (dostęp: 10.06.2015).

Biuro pełnomocnika Rządu ds. Osób Niepełnosprawnych, Rynek pracy, http://www. niepelnosprawni. gov.pl/p,80,rynek-pracy (dostęp: 02.06.2015).

Biuro Pełnomocnika Rządu ds. Osób Niepełnosprawnych, Uprawnienia pracodawcy zatrudniającego osobę niepełnosprawna, http://www.niepelnosprawni.gov. $\mathrm{pl} / \mathrm{p}, 67$,uprawnienia-pracodawcy-zatrudniajacego-osobe-niepelnosprawna (dostęp: 10.06.2015).

Centrum Badania Opinii Społecznej, Zadowolenie z życia - komunikat z badań 2015, http://www.cbos.pl/SPISKOM.POL/ 2015/K_003_15.PDF (dostęp: 5.05.2015).

Główny Urząd Statystyczny, Badanie Aktywności Ekonomicznej Ludności z lat 20092013, http://stat.gov.pl/ rocznik i_PLK_HTML.htm (dostęp: 1.05.10.2015).

Główny Urząd Statystyczny, Badanie Aktywności Ekonomicznej Ludności, Osoby niepełnosprawne na rynku pracy w IV kwartale 2014 r. Podsumowanie roku 2014, http://niepelnosprawni.gov.pl/container/niepelnosprawnosc-w-liczbach/rynekpracy/Daneb\%2 Oanalityczne\%20podsumowanie\%20za\%20IV\%20kwartal\%20 2014\%20r.\%202015.04.24.pdf (dostęp: 17.05.2015).

Główny Urząd Statystyczny, Narodowy Spis Powszechny Ludności i Mieszkań 2011, Ludność i gospodarstwa domowe. Stan i struktura ekonomiczno-społeczna. Część I. Ludność, stat.gov.pl/spisy-powszechne/nsp-2011/nso-2011-wyniki/ludnosci-gospodarwstwa-domowe-stan-i-struktura-spoleczno-ekonomiczna-czesc-iludnosc-nsp-2011,11,1.html (dostęp: 2.05.2015).

Główny Urząd Statystyczny, Badanie Aktywności Ekonomicznej Ludności, Badanie aktywności ekonomicznej ludności, http://stat.gov.pl/download/gfx/portal 
informacyjny/pl/defaultaktualnosci/5475/2/19/1/kwartalna_informacja_o_ aktywnosci_ekonomicznej_ludnosci_4kw2014.pdf (dostęp: 16.04.2015).

Główny Urząd Statystyczny, Narodowy Spis Powszechny z 2011, Pracujące osoby niepełnosprawne w wieku 16 lat i więcej wg stopnia niepełnosprawności, http://stat.gov. $\mathrm{pl} /$ spisy-powszechne/nsp-2011/ (dostęp: 11.05.2015).

Główny Urząd Statystyczny, Szkoły wyższe i ich finanse, lata 1998-2014, http://irsw. $\mathrm{pl}$ / raporty -i-publikacje/ (dostęp: 11.04.2015).

Narodowy Instytut Zdrowia Publicznego - Państwowy Zakład Higieny, Sytuacja zdrowotna ludności polski 2012, http://www.pzh.gov.pl/stan-zdrowia-ludnosci/ (dostęp: 17.05.2015).

Pentor Research International, Badania wpływu kierunku i poziomu wykształcenia na aktywność zawodową osób niepełnosprawnych. Raport końcowy, cz. 1, http://www. pfron.org.pl/ftp/dokumenty/Badania_i_analizy/Raport_CZESC_1z6_final.pdf (dostęp: 23.05.2015).

Śleboda R., Kierunek i poziom wykształcenia oraz aktywność zawodowa osób niepetnosprawnych, http://www.pfron.org.pl/kn/poprzednie-numery/118,Kierunek-ipoziom-wyksztalcenia-oraz-aktywnosc-zawodo wa-osob-z-niepelnosprawnosc. html (dostęp: 17.05.2015).

Żebrak A., Edukacja osób z niepełnosprawnością na poziomie szkolnictwa wyższego, http:// ngoteka.pl/bitstream/handle/item/32/edukacja_osob_z_niepelnosprawnoscia_na_ poziomie_szkolnictwa_wyzszego.pdf?sequence=1 (dostęp: 13.04.2015). 